\title{
ADMISSIBILITY OF PROPENSITY EVIDENCE IN PAEDOPHILIA CASES
}

\author{
C R WILLIAMS ${ }^{*}$ AND SANDRA DRAGANICH ${ }^{* *}$
}

[Application of the propensity evidence rule in paedophilia cases starkly highlights the tension between the two competing principles underlying the rule. Paedophilia is an area where the danger of prejudice is at its highest. At the same time the probative significance of propensity evidence may be great. In their habitual offending behaviour, paedophiles seek to establish opportunity and overcome the child's resistance to the sexual acts, typically through a long and drawn out grooming process in a manner calculated to minimise the risk of detection. Evidence of similar misconduct of the accused may be highly probative in establishing this pattern of paedophilia behaviour, and a proper factor to be taken account of in balancing probative value against risk of prejudice. In this context the Hoch/Pfennig test for admissibility is unduly strict. A more satisfactory balance between probative value and danger of prejudice may be achieved under the provisions of the uniform Evidence Acts and the pre-Hoch/Pfennig common law contained in s 398 A of the Crimes Act 1958 (Vic)]

\section{INTRODUCTION}

Application of the propensity evidence rule in paedophile cases starkly highlights the tension between the two competing principles underlying the rule. Few offences give rise to such a great risk of prejudice to an accused

\footnotetext{
* B Juris, LL B Hons (Monash), BCL (Oxon), LL D (Monash), FASSA, Barrister-atLaw (Vic), Sir John Barry Chair of Law, Monash University.

${ }^{* *}$ B Ec, LL B (Hons) (Monash), Barrister and Solicitor (Vic), Solicitor, Minter Ellison.
} 
person. Yet, as a result of the nature of offending itself, propensity evidence may be crucial in the successful prosecution of offenders. Typically compulsive, systematic and calculative in their behaviour, paedophiles often offend in such a way as to minimise the risk of detection. The nature and the effects of offending behaviour present serious difficulties in the successful prosecution of paedophiles where the only evidence available is frequently the testimony of the complainant or complainants. This article seeks to examine the various tests for admissibility of propensity evidence in their application to offences of paedophilia. It will be suggested that the balancing process that determines admissibility should not be limited to a search for striking similarities or other peculiarities in the specific acts alleged, but should take account also of overall patterns of offending behaviour.

\section{The NATURE of PAEdophiLIA}

\section{A Defining Paedophilia}

There is no common law or statutory definition of 'paedophilia" ${ }^{1}$ as there is no such crime recognised by the law. Rather paedophile activity is criminalised by offences such as rape, indecent assault, incest, sexual penetration of a child and other similar offences. ${ }^{2}$ At the medical level, paedophilia is defined via the use of three diagnostic criteria:

A. Over a period of at least 6 months, recurrent, intense sexually arousing fantasies, sexual urges, or behaviours involving sexual activity with a pre-pubescent child or children (generally aged 13 years or younger);

B. The fantasies, sexual urges, or behaviours cause clinically significant distress or impairment in social, occupational, or other important areas of functioning; and

C. The person is at least 16 years and at least 5 years older than the child or children in Criterion A. ${ }^{3}$

\footnotetext{
${ }^{1}$ Also spelled 'pedophilia'.

${ }^{2}$ Joint Committee on the National Crime Authority, Parliament of Australia

Organised Criminal Paedophile Activity (1995) [2.2]:

$<$ http://www.aph.gov.au/Senate/committee/acc_ctte/ncapedo/report/c02.htm> (26 March 2004).

3 American Psychiatric Association, Diagnostic and Statistical Manual of Mental Disorders $(D S M-1 V)\left(4^{\text {th }}\right.$ ed, 1994) 528.
} 
A purely medical definition is both over and under-inclusive of the relevant group of offenders. ${ }^{4}$ First, people falling within the definition are not necessarily offenders, as not all people act on their sexual fantasies. ${ }^{5}$ For purposes of the criminal law, the term 'paedophile' is restricted to persons who illegally act out their sexual fantasies or urges. Secondly, the definition does not capture all offenders; eg, a repeat child sex offender who has a job and is in an adult relationship may not fall within the medical definition due to an apparent lack of distress or impairment in social or occupational functioning. ${ }^{6}$ For present purposes, child sex offenders with no apparent 'impairment' are included in the definition of 'paedophile'.

The definition defines the offender target group in both biological and age terms; ie pre-pubescence and 13 years of age. Although it may be more meaningful for psychiatric purposes to classify paedophiles according to the biological characteristics of the child, ${ }^{7}$ the law delineates sexual offences against children by specified age groups. ${ }^{8}$ Conventionally the term 'paedophile' is used in Australia to refer to offences committed against children up to at least the age of 16 years, ${ }^{9}$ and this approach will be followed.

\section{B Profiling Offenders}

Identifying what the typical paedophile looks like, in terms of constructing a 'profile', is useful in understanding the nature of offending. The difficulty is that paedophilia covers a wide range of behaviour including the 'one off' fondling of a clothed child to regular and repetitive sexual intercourse with a number of children. The heterogeneity of offenders is well recognised by writers and it has been acknowledged that there is no such person as the 'typical paedophile': ${ }^{10}$ a 'single common denominator has yet to be found'. Another factor that limits paedophile profiling is the fact that most research is conducted on convicted offenders, who may not be representative of

\footnotetext{
${ }^{4}$ See generally Devon Polaschek, 'The Classification of Sex Offenders' in Tony Ward, D Richard Laws and Stephen Hudson (eds), Sexual Deviance Issues and Controversies (2003) 154, 156-8.

${ }^{5}$ Ibid 156.

${ }^{6}$ Ibid 157.

${ }^{7}$ Dennis Howitt, Paedophiles and Sexual Offences Againist Children (1995) 17.

${ }^{8}$ See, eg, Crimes Act 1958 (Vic) ss 45-49A.

${ }^{9}$ Joint Committee on the National Crime Authority, Parliament of Australia, above $n$ $2,[2.6]$.

${ }^{10}$ Howitt, above n 7, 11; Polaschek, above n 4, 154; David Finkelhor, Child Sexual Abuse: New Theory and Research (1984) 36.

${ }^{11}$ Howitt, above n 7, 33 .
} 
paedophiles generally. ${ }^{12}$ Also, this research assumes that the personality traits of convicted paedophiles are similar to those pre-disclosure of the offence. ${ }^{13}$

Notwithstanding these limitations, certain characteristics are prevalent among offenders and offending behaviour. For instance, the overwhelming majority of offenders are male: ${ }^{14}$ survey reports indicate that well over 90 per cent of paedophiles are men. ${ }^{15}$ However, several writers have conceded that female offenders may be under-represented in the statistics for a variety of reasons. ${ }^{16}$ Many paedophiles become aware of their sexual fantasies and orientations during adolescence, ${ }^{17}$ with paedophiliac behaviour typically starting during adolescence. ${ }^{18}$ And contrary to the 'dangerous stranger' image, the overwhelming majority of offenders are known to their victims ${ }^{19}$ - either as a family member, neighbour, family friend or an adult met through the victim's peer associations - with Victorian statistics indicating that over 90 per cent of

12 John Murray, 'Psychological Profile of Pedophiles and Child Molesters' (2000) 134(2) The Journal of Psychology 211, 211, 213, 220. See also Jean Renvoize, Innocence Destroyed: A Study of Child Sexual Abuse (1993) 109-10. Renvoize discusses a study by Professor D J West which found that, compared to convicted offenders, paedophiles who had not been charged with any offences tended to be more confident, assertive, better educated, more representative of professional men, and more likely to have jobs where their work brought them into contact with children.

${ }^{13}$ Kevin Wallis, 'Perspectives on Offenders' in Freda Briggs (ed), From Victim to Offender: How Child Sexual Abuse Victims Become Offenders (1995) 1, 3.

${ }^{14}$ Joint Committee on the National Crime Authority, Parliament of Australia, above $\mathrm{n}$ 2, [2.17]; Murray, above n 12, 211; Freda Briggs (ed), From Victim to Offender: How Child Sexual Abuse Victims Become Offenders (1995) ch xii.

${ }^{15}$ Joint Committee on the National Crime Authority, Parliament of Australia, above $n$ 2, [2.17]. See also Vikki Petraitis and Chris O'Connor, Rockspider: The Danger of Paedophiles - Untold Stories (1999) 123.

${ }^{16}$ For discussion on reasons why female offenders are less likely to be reported see: Briggs,, above n 14, ch xii; T Marvasti, 'Incestuous Mothers' (1986) 7(4) American Journal of Forensic Psychiatry (1986) 63, 63-9; Howitt, above n 7, 49-50; Renvoize, above n 12, 115-17.

${ }^{17}$ Joint Committee on the National Crime Authority, Parliament of Australia, above $n$ $2,[2.18]$.

${ }^{18}$ Wallis, above n 13, 11; Petraitis and O'Connor, above n 15, 131. However, some offenders may not start offending until mid-life: see Murray, above n 12, 212; Joint Committee on the National Crime Authority, Parliament of Australia, above n 2, [2.18].

${ }^{19}$ Petraitis and O'Connor, above n 15, 45; Wallis, above n 13, 2; Renvoize, above $\mathrm{n}$ 12, 101; Murray, above n 12, 214. 
victims knew their offender. ${ }^{20}$ Indeed, research suggests that fathers are the most common abusers with claims that natural fathers represent as high as 36 per cent of all offenders. ${ }^{21}$ In terms of the commission of the offence, most sexual abuse takes place in the offender's home or other private place. ${ }^{22}$

\section{Theories of Paedophilia}

Various theories have been developed to explain and assist understanding of paedophile behaviour. One model that recognises and attempts to explain the diversity in behaviour is Finkelhor's 'Four-Preconditions Model of Sexual Abuse'. ${ }^{23}$

Under this theory, Finkelhor identifies four preconditions that must be satisfied before the sexual abuse occurs:

1. A potential offender needs to have some motivation to sexually abuse a child;

2. The potential offender has overcome internal inhibitions against sexually abusing a child;

3. The potential offender has overcome external inhibitions against sexually abusing a child; and

4. The potential offender has overcome a child's resistance to the abuse. $^{24}$

Of particular interest are preconditions 3 and 4, as they provide insight into offender behaviour; ie how offenders go about sexually abusing children.

${ }^{20}$ Petraitis and O'Connor, above n 15, 214.

21 Renvoize, above n 12, 101 citing Goddard's statement for the Law Reform Commission of Victoria.

${ }^{22}$ See Petraitis and O'Connor, above n 15, 207-16: statistics collected by the Child Exploitation Squad in Victoria between 1988 and 1996 indicate that 50 per cent of all child sex abuse allegations investigated by the Squad related to offences allegedly committed in the offender's home. This percentage is likely to understate the figure for all offending as the Squad generally did not investigate intra-familial or incest allegations, except where there were multiple victims. See also Canadian Government, Report of the Committee of Sexual Offences Against Children and Youths, Sexual Offences Against Children (1984) Vol 1, 202 where results of a National Police Force Survey indicate that 57 per cent of child sexual assault occurred in private houses.

${ }^{23}$ Finkelhor, above n 10, 33-67. Finkelhor theorises that a multi-factor model helps to explain behavioural diversity.

${ }^{24}$ Ibid 54. 


\section{$1 \quad$ Overcoming External Inhibitions}

Overcoming external inhibitions involves breaking down environmental barriers and creating opportunities to offend. Because, by definition, paedophiles' sexual urges and fantasies are intense and recurrent, they often go to considerable lengths to create opportunities to offend and it is common for paedophiles to establish their lives around children. They frequently place themselves in occupations, sporting or service activities, or family situations in which they have access to children. ${ }^{25}$ For instance, offenders may become childcare workers, priests/ministers or church volunteers, scout leaders, teachers or marry women with children. Indeed, Renvoize has commented that increasingly more cases are surfacing of abuse by the very people whose responsibility it is to care for the children they abuse. ${ }^{26}$ Assuming such a role not only gives an offender opportunity to be alone with and have power over children, it also works to minimise suspicion and detection as we tend to regard people in such roles as child carers and not abusers.

Lack of parental supervision is noted as one of the most important factors in overcoming external inhibitors. ${ }^{27}$ Other important factors centre on the child's family structure including: a mother who is absent or ill; a mother who is not close or protective or who is dominated or abused by her husband; and social isolation of the family. ${ }^{28}$ These factors provide opportunity to have unsupervised access to children and help to provide the perfect victim - an emotionally neglected child who is particularly vulnerable and looking for love and attention. ${ }^{29}$

\footnotetext{
${ }^{25}$ Petraitis and O'Connor, above n 15, 33, 123, 131; Renvoize, above n 12, 110. See generally Briggs, above $\mathrm{n} 14$, in which offenders discuss how they establish their lives to be around children. This is one aspect of behaviour which sets parent offenders apart, as they (typically) have the opportunity to offend by virtue of being a parent.

26 Renvoize, above n 12, 110. In Adelaide in 2004, a former Anglican Minister, former Salvation Army Minister, a Surf Life Saving Coach, a Scouts leader, a Church of England Boys Society leader and several Catholic school teachers were all charged with paedophile offences: see

$<$ http://www.news.com.au/common/story_page/0,4057,10427621\%255E26462,00.ht $\mathrm{ml}>$ (13 August 2004).

${ }^{27}$ Finkelhor, above n 10, 58 .

${ }^{28}$ Ibid 57.

${ }^{29}$ Renvoize, above n 12, 108-9; Wallis, above n 13, 6. See also Roland Summit, 'The Specific Vulnerability of Children' in R Kim Oates (ed), Understanding and Managing Child Sexual Abuse (1990) 59, 62.
} 
Offenders are typically 'seen as conventional, protective and good family men with stable work histories' ${ }^{30}$ When asked about her experiences in treating child sex offenders, a senior child advocate commented:

[T]hey're usually very pleasant superficially; some of them have been overtly sickeningly charming ... and they've got this propensity to suddenly change from that to being very nasty indeed ... I feel the majority are like that ... They can be trying to give a good impression but then they turn on you .... It's really interesting the way their behaviour changes and you see in them the person who will threaten the child. $^{31}$

This superficial 'nice guy' image helps to establish trust with the victim and their parents, ${ }^{32}$ effectively helping to secure preconditions 3 and 4 . It also minimises the risk of detection as people may refuse to believe that nice guys sexually abuse children.

\section{Overcoming the Child's Resistance}

Paedophiles are commonly obsessive, calculative and systematic in their offending behaviour. They often show great patience in selecting their victims $^{33}$ and spend considerable amounts of time 'grooming' victims and their families before offending begins. ${ }^{34}$ This obsessiveness is well summed up by one offender's admission: 'I've spent 95 per cent of my time grooming and raping children' ${ }^{35}$ One psychologist has commented that the 'most common form of seduction is to insinuate themselves into the trust of the child victim and when possible, the trust of that child's parents or guardians'. ${ }^{36}$ Parents who have entrusted the care of their child to the 'friendly' paedophile often feel deep conflict when suspicions or allegations of abuse arise: there is a tendency to deny the abuse where parents feel responsible in that they permitted or even encouraged their child to spend time alone with the offender. ${ }^{37}$

${ }^{30}$ Wallis, above n $13,2$.

${ }^{31}$ Renvoize, above n 12, 106-7.

${ }^{32}$ Renvoize, above n 12, 108; Petraitis and O'Connor, above n 15, 101; Howitt, above n 7,79 .

${ }^{33}$ Petraitis and O'Connor, above n 15, 132; Summit, above n 29, 70.

${ }^{34}$ See generally Renvoize, above n 12, 108-9; Howitt, above n 7, 83-92; Wallis, above n 13, 8-10; Summit, above n 29, 71-2; Joint Committee on the National Crime, above n 2, [2.19].

${ }^{35}$ Petraitis and O'Connor, above n 15, 101.

${ }^{36}$ Wallis, above $\mathrm{n} 13,6$. See also Howitt, above n 7, 9.

${ }^{37}$ See generally Summit, above n 29, 65-9. 
Although modus operandi will differ, many offenders spend much time breaking down the child's inhibitions and defences to the sexual act. ${ }^{38}$ Enticements include playing games, giving money and other gifts, and even choosing children previously victimised by another offender. ${ }^{39}$ Once the child's trust is established, offenders may begin to desensitise the child to sexual advances; they may start with innuendo and subtle advances and gradually progress to more overt forms of abuse. ${ }^{40}$ If the child resists being sexually touched, the paedophile may stop the contact, revert back to nonsexual grooming, and try again later once they feel it is safer to do so. ${ }^{41}$ Often, the child will not even realise that they are being sexually abused where the process is drawn out and trust has been established. ${ }^{42}$ When asked to write a 'manual' for offending, a paedophile wrote:

Play, talking, giving special attention, trying to get the child to initiate contact with me. Get the child to feel safe to talk with me. From here I would initiate different kinds of contact, such as touching the child's back, head. Testing the child to see how much she would take before she would pull away. ${ }^{43}$

\section{$3 \quad$ Non-disclosure}

Once the sexual abuse occurs, offenders seek to minimise the risk of being detected $^{44}$ and typically take no responsibility for the abuse by either blaming the child or denying that the offences took place. ${ }^{45}$ Non-disclosure may be achieved by moving on to another victim, threats, or attempts to bribe the child into 'keeping the secret'. The grooming process itself may be effective in achieving non-disclosure:

By subtly turning this special friendship into sexual exploitation the [offender] converts the child gradually into a guilty, disillusioned

\footnotetext{
${ }^{38}$ Petraitis and O’Connor, above n 15, 132. See also Summit, above n 29, 71-2.

${ }^{39}$ Howitt, above n 7, 79-80.

${ }^{40}$ Renvoize, above n 12, 108; Wallis, above n 13, 9 .

${ }^{41}$ Howitt, above n 7, 84.

${ }^{42}$ Wallis, above $\mathrm{n} 13,9$.

${ }^{43}$ Howitt, above n 7, 80-1.

${ }^{44}$ Wallis, above n 13, 9. See also Petraitis and O'Connor, above n 15, 100-1.

${ }^{45}$ Briggs, above $\mathrm{n} \mathrm{14}$, viii, $\mathrm{x}$. Briggs comments, at $\mathrm{x}$, that 'child sex abuse has the reputation of being the world's most consistently denied offence'. See also Howitt, above $n$ 7, 93-102. Howitt discusses how offenders seek to minimise their responsibility through denial or distorted thinking that they were simply responding to the child's sexual advances.
} 
expatriate, dependent now on the molester to preserve the appearance of connection to family and friends through a conspiracy of silence. ${ }^{46}$

There are many reasons why child victims do not disclose the sexual abuse. It is common for the paedophile to tell the child that nobody will believe them or that it was the child's fault because they didn't say 'No' and that they enjoyed it. ${ }^{47}$ This can be a particularly effective way of ensuring nondisclosure as children are taught to trust and believe adults and may very well have enjoyed the attention given to them, the enticements, and some of the physical stimulation. ${ }^{48}$ Where the offender is the parent or guardian, the child may be warned 'if you tell, I'll go to jail and it will be all your fault'49 and keep silent for fear of 'causing' a family break up. Children led to believe that the abuse was their fault may be scared, embarrassed or ashamed to disclose the abuse. ${ }^{50}$ The child may simply be too young to understand that they are being abused ${ }^{51}$ or find the abuse so painful that they disassociate themselves from it as a way of dealing with the situation. ${ }^{52}$

And efforts to remain undetected are largely successful, with most offenders not reported. ${ }^{53}$ Because many children do not disclose the offences, the proportion of unreported offending can only be estimated. However, some data is available. In a survey of parents with children living at home between the ages of 6 and 14, of the parents who had themselves been victims of sexual abuse as a child, only 39 per cent said that they had told someone about the experience within a year of its occurrence. ${ }^{54}$ A Parliamentary Committee Report has noted the case of Alister John Caroll who admitted to sexual contact with between 100 and 200 children over a 28 year period; only 5 of those children were known to have complained to others during those 28 years. ${ }^{55}$

\footnotetext{
${ }^{46}$ Summit, above n 29, 72 .

${ }^{47}$ Wallis, above $\mathrm{n} 13,9-10$.

${ }^{48}$ Summit, above n 29, 71-2; Briggs, above n 14, ch xiii.

${ }^{49}$ Wallis, above $\mathrm{n} 13,9-10$.

${ }^{50}$ Petraitis and O'Connor, above n 15, 128.

51 Ibid 207-16: statistics collected by the Child Exploitation Squad in Victoria between 1988 and 1996 indicate that 33 per cent of alleged offenders investigated by the Squad were regarded as preferring victims 10 years or younger.

${ }^{52}$ Summit, above n 29, 63.

${ }^{53}$ Finkelhor, above n 10, 73; Joint Committee on the National Crime, above n 2, [2.22]; Briggs, above n 14, xiv.

${ }^{54}$ Finkelhor, above n 10, 73.

55 Joint Committee on the National Crime, above n 2, [2.22] note 56 citing D G Sturgess QC, Director of Public Prosecutions, Queensland, An Inquiry into Sexual
} 
Paedophilia studies and recidivism rates highlight the repetitive and chronic nature of offending behaviour. International and Western Australian statistics show that, without intervention, 80 per cent of imprisoned child sex offenders re-offend within one year of being released. ${ }^{56}$ There have also been claims that paedophiles, on average, offend against 150 male or 20 female victims depending on their orientation. ${ }^{57}$ Although these statistics are startling, the very nature of paedophilia compels the offender to move from victim to victim. As a child matures, they are no longer attractive to the paedophile, who is left to find another victim to satisfy their fantasy. What all of this research bears out is the fact that many paedophiles can and do victimise a number of children. The majority of offences are not reported and even when allegations are made, most alleged offenders escape prosecution and conviction. ${ }^{58}$

\section{The Effects of Paedophile Offending}

Although the effects of child sexual abuse are diverse, ${ }^{59}$ it has been recognised that ' $[\mathrm{t}]$ here is no doubt that serious social and psychological harm can be caused to some children by sexual abuse in childhood' ${ }^{60}$ The extent of trauma suffered by the child will depend on a variety of factors including the relationship between the paedophile and child, the number and frequency of assaults, whether physical force was used, the type of abuse committed and the availability of support and treatment after the offending has taken place. ${ }^{61}$ The effects include disassociation, anxiety, depression, low self-esteem, selfhatred, self-destructive behaviour, eating disorders, criminal behaviour, substance abuse, revictimisation, psychiatric breakdown, and suicide.$^{62}$ Where the victim has been abused by a same sex offender, the child can be left

Offences Involving Children and Related Matters: Report Queensland Government Printer, Brisbane, 28 November 1985, paras 4.43ff.

${ }^{56}$ Briggs, above n 14, xiv. See also Renvoize, above n 12, 124. Renvoize notes Ray Wyre's comments that unless treated, 'fixated' paedophiles abused another 100 children after being released and that 55 per cent of all child sex abusers were reconvicted.

${ }^{57}$ Howitt, above n 7, 77. See also Murray, above n 12, 212.

${ }^{58}$ Briggs, above $\mathrm{n} 14$, xiv. Briggs notes that only about one per cent of reported offenders receive prison sentences.

${ }^{59}$ For detailed discussion of the after-effects of child sexual abuse, see Renvoize, above $\mathrm{n} 12,144-51$.

${ }^{60}$ Howitt, above n 7, 63.

${ }^{61}$ Renvoize, above n 12, 145 .

${ }^{62}$ Ibid 144-8. 
confused about their sexual identity. ${ }^{63}$ And, controversially, it is recognised that victims of paedophilia are more likely to become sex offenders themselves. ${ }^{64}$

Renvoize sums up the varying effects of abuse in the following terms:

I have not over-dramatized the after-effects of [child sexual abuse] ... it is obvious that most of those experiencing the milder forms of abuse are able as they grow up to put these aside and proceed with their lives, undoubtedly a little damaged ... There are, however, incalculable numbers of victims who have had to face many years of intense stress and pain before arriving at comparative calm, and many thousands more whose lives have been ruined for ever beyond repair. This is a fact that it is not possible to over-dramatize. ${ }^{65}$

\section{Tests For The Admissibility Of Propensity EVIDENCE}

\section{A Lord Herschell's Formulation and the Common Law}

Propensity or similar fact evidence may be defined as all evidence which shows or tends to show that on some other occasion the accused acted in a way more or less similar to the way in which the prosecution alleges the accused acted on the occasion the subject of the present charge. ${ }^{66}$ Such

\footnotetext{
${ }^{63}$ Wallis, above $\mathrm{n} 13,11$.

${ }^{64}$ See, eg, Wallis, above n 13, 11; Renvoize, above n 12, 149; Finkelhor, above n 10, 35; Howitt, above n 7, 58.

${ }_{65}^{65}$ Renvoize, above n 12, 149.

${ }^{66}$ The expressions 'propensity evidence' and 'similar fact evidence' are here treated as equivalent expressions. An alternative approach is to treat propensity evidence, as defined above, as subdivided into two categories, 'relationship evidence' (where the victim is the same) and 'similar fact evidence' (where the victim is different); see $R v$ Best [1998] 4 VR 603, 606 (Callaway JA); KRM v The Queen (2001) 206 CLR 221, 229 (McHugh J). This subdivision does not seem to offer any clear benefit, and may create uncertainty as to the principles governing the admissibility of relationship evidence; see Jonathan Clough, 'Section 398A of the Crimes Act 1958 (Vic): Pfennig Resurrected?' (2000) 24 Criminal Law Journal 8. The definition adopts what is sometimes termed a 'disclosure approach', rather than a more limited 'purpose approach'; contrast with Andrew Ligertwood, Cross on Evidence ( $7^{\text {th }}$ Aust ed, 2004) 639. A wide definition focuses attention on the vice of propensity evidence, which is its potential for prejudice. All evidence which shows the accused performed broadly similar acts on other occasions possesses this potential for prejudice and is therefore brought within the expression.
} 
evidence is subject to a general exclusionary rule that prohibits the prosecution from leading the evidence, not because it is 'inherently irrelevant', but because it would be unfairly prejudicial to the accused. ${ }^{67}$ The prejudice to be avoided has been identified as the 'over-strong tendency to believe the defendant guilty of the charge merely because he is a likely person to do such acts' and 'the tendency to condemn, not because he is believed to be guilty of the present charge, but because he has escaped unpunished from other offences'. ${ }^{68}$

Notwithstanding its potential for prejudice, propensity evidence is admissible in many situations. Prior to the decision in DPP $v$ Boardman ${ }^{69}$ the leading case on propensity evidence was Makin $v$ Attorney-General (NSW) ${ }^{70}$ The formulation of Lord Herschell in that case was treated as authoritative of the admissibility of propensity evidence, ${ }^{71}$ notwithstanding that the two sentences comprising the formulation (the first one of exclusion and the second one of inclusion) could be seen to involve a logical contradiction. ${ }^{72}$ Two major approaches have been adopted in giving a workable meaning to Lord Herschell's formulation. The first approach involves distinguishing between evidence which has relevance only via propensity and evidence which has relevance other than via propensity, with only the latter type admissible. ${ }^{73}$

${ }^{67}$ DPP v Boardman [1975] AC 421, 456 (Lord Cross); Perry v The Queen (1982) 150 CLR 580, 585 (Gibbs CJ).

${ }^{68}$ Wigmore, Evidence (1940), Vol 1, 650.

${ }^{69}[1975]$ AC 421.

${ }^{70}$ [1894] AC 57.

${ }^{71}$ Lord Herschell stated at 65:

It is undoubtedly not competent for the prosecution to adduce evidence tending to show that the accused has been guilty of criminal acts other than those covered by the indictment, for the purpose of leading to the conclusion that the accused is a person likely from his criminal conduct or character to have committed the offence for which he is being tried. On the other hand, the mere fact that the evidence adduced tends to show the commission of other crimes does not render it inadmissible if it be relevant to an issue before the jury, and it may be so relevant if it bears upon the question whether the acts alleged to constitute the crime charged in the indictment were designed or accidental, or to rebut a defence which would otherwise be open to the accused.

${ }^{72}$ See CR Williams, 'Approaches to Similar Fact Evidence: England and Australia' in Mirfield and Smith (eds), Essays for Colin Tapper (2003) 21, 24. The two sentences of Lord Herschell's formulation constitute an example of what Professor Julius Stone has termed 'Legal Categories of Competing Reference': J Stone, Legal System and Lawyers' Reasoning (1964) 248-52.

${ }^{73}$ This distinction forms the basis of many judicial interpretations of the propensity evidence rule. See, eg, the judgment of Lord Hailsham LC in DPP v Boardman 
The second approach involves treating the balance between probative value and risk of prejudice in each case as determining the admissibility of propensity evidence. ${ }^{74}$ This approach involves treating Lord Herschell's formulation not as containing two conflicting rules, one of exclusion and one of inclusion, but rather as referring to two competing principles. ${ }^{75}$ What Lord Herschell's formulation requires is that these two competing factors, the probative value of the evidence and the risk of prejudice, be weighed one against the other. If the risk of prejudice is great and the probative value small by comparison, the evidence should be rejected. If the probative value is great and the risk of prejudice slight by comparison, the evidence should be admitted. $^{76}$

[1975] AC 421, 453, and the judgments of Gibbs CJ in Perry v The Queen (1982) 150 CLR 580, 585 and in Sutton v The Queen (1984) 152 CLR 528, 533.

74 'Probative value' is defined as 'the extent to which the evidence could rationally affect the assessment of the probability of the existence of a fact in issue': LexisNexis Butterworths, Butterworths Concise Australian Legal Dictionary $\left(2^{\text {nd }}\right.$ ed, 1998) 350.

${ }^{75}$ On the distinction between rules and principles, see R M Dworkin, Taking Rights Seriously (1977) chs 2 and 3.

${ }^{76}$ See generally, L H Hoffman, 'Similar Facts after Boardman' (1975) 91 Law Quarterly Review 193; Donald Piragoff, Similar Fact Evidence Probative Value and Prejudice (1981); Peter Mirfield, 'Similar Facts - Makin Out?' [1987] Criminal Law Journal 83; Adrian Zuckerman, The Principles of Criminal Evidence (1989) ch 12; Peter Mirfield, 'Similar Facts in the High Court of Australia' (1990) 106 Law Quarterly Review 199; Annalise Acorn, 'Similar Fact Evidence and the Principle of Inductive Reasoning: Making Sense' (1991) Oxford Journal of Legal Studies 63; Colin Tapper, 'The Probative Force of Similar Fact Evidence' (1992) 108 Law Quarterly Review 26; Andrew Palmer, 'The Scope of the Similar Fact Rule' (1994) 16 Adelaide Law Review 161; Colin Tapper, 'Dissimilar Views of Similar Facts' (1995) 111 Law Quarterly Review 381; Rajiv Nair, 'Weighing Similar Fact and Avoiding Prejudice' (1996) 112 Law Quarterly Review 262; Andrew Palmer, 'Propensity, Coincidence and Context: The Use and Admissibility of Extraneous Misconduct Evidence in Child Sexual Abuse Cases' (1999) 4 Newcastle Law Review 46; Kenneth Arenson, 'Propensity Evidence in Victoria: a Triumph for Justice or an Affront to Civil Liberties' (1999) 23 Melbourne University Law Review 263; Jonathan Clough, 'Section 398A of the Crimes Act 1958 (Vic): Pfennig Resurrected' (2000) 24 Criminal Law Journal 8; Geoffrey Flatman and Mirko Bagaric, 'Non-similar Fact Propensity Evidence: Admissibility, Dangers and Jury Directions' (2001) 75 Australian Law Journal 190; David Hamer, 'The Structure and Strength of the Propensity Inference: Singularity, Linkage and the Other Evidence' (2003) 29 Monash University Law Review 137 ; CR Williams, 'Approaches to Similar Fact Evidence: England and Australia' in Mirfield and Smith (eds), Essays for Colin Tapper (2003) 21. 
The decision of the House of Lords in DPP v Boardman ${ }^{77}$ and that of the High Court in Perry $v$ The Queen ${ }^{78}$ gave considerable support to the view that the Makin formulation involves a comparison of probative value and prejudice in the context of each particular case. Such an approach gives frank recognition to the real issues involved in determining whether propensity evidence is admissible, and leaves the judge with a wide measure of discretion in determining whether to admit propensity evidence. Subsequent developments in Australia, both common law and statutory, however have produced a more complex situation. Three distinct sets of rules and principles now govern the admissibility of propensity evidence.

\section{B The 'No Rational View of the Evidence Consistent with Innocence' Test}

In a series of decisions following Perry $v$ The Queen, the High Court sought to refine its approach to propensity evidence by expressing in various ways the nature and extent of the probative force required to justify admissibility. ${ }^{79}$ A clear view emerged with the decisions in Hoch $v$ The Queen ${ }^{80}$ and Pfennig $v$ The Queen. ${ }^{81}$ In Pfennig the majority, comprising Mason CJ, Deane and Dawson JJ expressed the requirement for admissibility as follows:

Because propensity evidence is a special class of circumstantial evidence, its probative force is to be gauged in the light of its character as such. But because it has a prejudicial capacity of a high order, the trial judge must apply the same test as a jury must apply in dealing with circumstantial evidence and ask whether there is a rational view of the evidence that is consistent with the innocence of the accused. Here 'rational' must be taken to mean 'reasonable' and the trial judge must ask himself or herself the question in the context of the prosecution case; that is to say, he or she must regard the evidence as a step in the proof of that case. Only if there is no such view can one safely conclude that the probative force of the evidence outweighs its

\footnotetext{
${ }^{77}$ [1975] AC 421.

78 (1982) 150 CLR 580.

79 Sutton v The Queen (1984) 152 CLR 528, 533; De Jesus v The Queen (1986) 61

ALJR 1; Hoch v The Queen (1988) 165 CLR 292; Harriman v The Queen (1989) 167

CLR 590; $S v$ The Queen (1989) 168 CLR 266; Thompson v The Queen (1989) 169

CLR 1; Bv The Queen (1992) 175 CLR 599.

${ }^{80}$ Hoch $v$ The Queen (1988) 165 CLR 292.

${ }^{81}$ (1995) 182 CLR 461. For discussion of Pfennig $v$ The Queen see Tapper, Dissimilar Views of Similar Facts (1995) 111 Law Quarterly Review 381.
} 
prejudicial effect. And, unless the tension between probative force and prejudicial effect is governed by such a principle, striking the balance will continue to resemble the exercise of a discretion rather than the application of a principle. ${ }^{82}$

The formulation of no 'rational view of the evidence that is consistent with the innocence of the accused' comes from the elaboration of the criminal standard of proof sanctioned by the courts for directing the jury in cases of circumstantial evidence. ${ }^{83}$ Thus, as a criterion of admissibility the judge is required to determine whether the propensity evidence satisfies her or him beyond reasonable doubt of the guilt of the accused. Such a test is unsatisfactory for three reasons. First, it is difficult to see how a judge can be so satisfied when the evidence is sought to be led as part of the prosecution case. At this stage the judge may not be aware of the evidence to be called by the defence. Second, if applied literally the test would be far more restrictive in its operation than other judicial formulations of the similar fact rule ${ }^{84} \mathrm{~A}$ requirement that propensity evidence establish guilt beyond reasonable doubt is far more demanding than that the evidence possesses 'striking similarity' or 'sufficient probative value to justify admissibility notwithstanding its potential for prejudice'. Finally, it is unsatisfactory to require the judge to ask her or himself when considering admissibility precisely the same question the jury is to ask itself in determining guilt. Questions must arise as to the perceived impartiality of the judge as the trial progresses if, in admitting propensity evidence, the judge has effectively said he or she is satisfied beyond reasonable doubt as to the guilt of the accused.

In its most recent decision on propensity evidence, Phillips $v$ The Queen ${ }^{85}$ the High Court affirmed its decision in Pfennig. In a joint judgment, Gleeson CJ, Gummow, Kirby, Hayne and Heydon JJ rejected modifications of the Pfennig test adopted by the Queensland Court of Appeal in $R v O^{\prime}$ Keefe, ${ }^{86}$ stating 'it is

\footnotetext{
82 (1995) 182 CLR 461, 482-3. In his judgment, McHugh J preferred the traditional common law approach of balancing probative value against risk of prejudice in the context of the particular case.

${ }^{83} R v$ Hodge (1838) 2 Lewin 227; 168 ER 1136; Green v The Queen (1975) 11 ALR 503; Barca v The Queen (1975) 133 CLR 82; Sutton v The Queen (1984) 152 CLR 528; Shepherd $v$ The Queen (1990) 170 CLR 573.

${ }^{84}$ Note $R v$ Best [1998] 4 VR 603, 608-9 (Callaway JA).

${ }^{85}$ [2006] HCA 4.

${ }^{86}$ [2000] 1 Qd R 564.
} 
for this Court alone to determine whether one of its previous decisions is to be departed from or overruled'. ${ }^{87}$

One particular application of the no rational view of the evidence consistent with innocence test of particular relevance in paedophilia trials is the proposition that propensity evidence of other victims is not admissible if there exists a possibility of concoction between the victims. In Hoch $v$ The Queen, ${ }^{88}$ the accused was convicted on three counts of sexual molestation of boys aged under 14. The counts were joined in one indictment and an application for separate trials was refused. On appeal it was submitted that the evidence of each boy was inadmissible as propensity evidence on the basis that, because of demonstrated association between the boys and their antipathy towards the accused, there was a real chance that their evidence was concocted. The High Court accepted the submission and allowed the appeal of the accused. In a joint judgment, Mason CJ, Wilson and Gaudron JJ posited the test of 'no other rational view of the evidence' and held that 'the possibility of concoction - not a probability or real chance of concoction' was sufficient to render the evidence inadmissible. ${ }^{89}$ Their Honours stated:

In cases where there is a possibility of joint concoction there is another rational view of the evidence. That rational view - viz joint concoction - is inconsistent both with the guilt of the accused person and with the improbability of the complainants having concocted similar lies. It thus destroys the probative value of the evidence which is a condition precedent to its admissibility.

\footnotetext{
${ }^{87}$ Above $\mathrm{n}$ 85, [60]. There are perhaps indications in their Honours joint judgment that the Court may be willing to re-consider the Pfennig test. In an almost Delphic passage their Honours stated at [61] - [62]:

Nothing said in these reasons should be understood as indicating any view about whether it is necessary, or would be desirable, to revisit what is said by this Court in Pfennig $v$ The Queen.

Having regard to the basis upon which the present appeal should be decided and to the course taken in argument, it is sufficient to make only two points. First, Pfennig $v$ The Queen must be understood against the background of the decisions, especially the decisions of this Court, that preceded it. Secondly, taking sentences or parts of sentences in reasons for judgment and divorcing them from the context in which they sit is to invite error.

${ }^{88}$ (1988) 165 CLR 292.

${ }^{89}$ Ibid 296.
} 
Thus, in our view, the admissibility of similar fact evidence in cases such as the present depends on that evidence having the quality that it is not reasonably explicable on the basis of concoction. ${ }^{90}$

It is submitted that the 'no possibility of concoction test' application of the Pfennig test is an unduly strict approach to adopt in paedophilia trials. In England the test was rejected by the House of Lords in $R v H,{ }^{91}$ and has been overturned by statute in Victoria, Queensland and Western Australia. ${ }^{92}$ If applied it would clearly have led to rejection of the evidence in DPP $v$ Boardman, ${ }^{93}$ and indeed in cases where the evidence is far stronger than in Boardman. It is difficult to see how the test can be applied, since the issue of possible concoction must be determined before the evidence is tested. The proposition that evidence must be totally convincing in order to be admitted is contrary to the general rule that facts which are a condition precedent to admissibility must be established to the standard of the balance of probabilities. ${ }^{94}$ The effect of the decision in Hoch, if applied literally, would be to render propensity evidence inadmissible in most cases of incest with multiple family members and other cases in which the alleged predatory conduct of the accused was focused on child members of a group. There is no inherent objection to some measure of collaboration between victims in such cases. Indeed, in such cases discussion between victims as a precursor to making a formal complaint might be expected and would not, of itself, demonstrate that the accused's prospects of a fair trial had been prejudiced. ${ }^{95}$ Where collaboration is or may be present it would be an easy thing for the defence to allege concoction which, even in the absence of any supporting evidence would be likely to prevent the evidence from satisfying the Hoch 'no possibility of concoction' test.

\section{The Uniform Evidence Acts}

The provisions of the Evidence Act 1995 (Cth and NSW) 2001 (Tas) require the court to engage in a balancing of probative value and potential for

\footnotetext{
${ }^{90}$ Ibid 296-7. In $R v$ Colby [1999] NSWCCA 261, the New South Wales Court of Appeal interpreted $R v$ Hoch narrowly as requiring a real danger of concoction.

${ }^{91}$ [1995] 2 AC 596.

${ }^{92}$ See Part III (B) below.

${ }^{93}[1975]$ AC 421.

${ }^{94}$ Wendo $v$ The Queen (1963) 109 CLR 559; $R v$ Savage [1970] Tas SR 137; $R v$ Attard and Mifsud [1970] 1 NSWR 750, 758; $R$ v Browne-Kerr [1990] VR 78; DPP v Alexander (1990) 120 ALR 673, 682. Note Evidence Act 1995 (Cth and NSW) 2001 (Tas) $\mathrm{s} 142$.

${ }^{95} R \cup A L P[2002]$ VSCA 210, [51] (Eames JA).
} 
prejudice. Section 97 deals with 'tendency evidence', ie evidence tendered to prove 'that a person has or had a tendency (whether because of the person's character or otherwise) to act in a particular way, or to have a particular state of mind'. Section 98 deals with 'coincidence evidence', ie evidence that two or more related events occurred tendered to prove that 'because of the improbability of the events occurring coincidentally, a person did a particular act or had a particular state of mind'. The test prescribed for admissibility is the same for both classes of evidence. Tendency evidence and coincidence evidence are not admissible if 'the court thinks that the evidence would not, either by itself or having regard to other evidence adduced or to be adduced by the party seeking to adduce the evidence, have significant probative value'. The striking of a balance between probative value and risk of prejudice is achieved by s 101 which provides that tendency evidence or coincidence evidence about an accused that is adduced by the prosecution cannot be used against the accused 'unless the probative value of the evidence substantially outweighs any prejudicial effect it may have on the [accused]'.

The balancing process incorporates a bias against admissibility by requiring that the probative value of the evidence must both be significant and must 'substantially' outweigh any prejudicial effect it might have on the accused. The significance of this bias is difficult to quantify. One view is that the use of the word 'substantially' may not lead to significantly different results under the uniform Evidence Acts to that which applied at common law pre-Pfennig and Hoch. It was not the case at common law that an 'insubstantial' preponderance of probative value over risk of prejudice would lead to admissibility. On this analysis the word 'substantially' emphasises the need for care in admitting propensity evidence, a need which was always recognised at common law. Alternatively, the word 'substantially' may be viewed as having a significant effect in tilting the scales against admissibility. In truth, the word 'substantially' can probably have as much or as little effect as the individual judge wishes. In any event, the balancing process under the uniform Evidence Acts is essentially similar to the approach taken at common law prior to Hoch/Pfennig, and both at common law and under the uniform Evidence Acts the judge is invested with considerable flexibility to have regard to the needs of the particular case.

In New South Wales, prior to the decision in $R v$ Ellis, ${ }^{96}$ a number of cases had adopted the view that s 101 incorporates the Pfennig test for

\footnotetext{
${ }^{96}$ (2003) 58 NSWLR 700.
} 
admissibility. ${ }^{97}$ Such an approach was incorrect in principle. The Acts predate the decision in Pfennig, ${ }^{98}$ and it is not correct to seek to interpret them as incorporating subsequent changes in the common law. In $R v$ Ellis, ${ }^{99}$ the New South Wales Court of Criminal Appeal rejected the earlier cases. Spigelman CJ, with whom Sully and O'Keefe JJ agreed, stated:

The continued application of a 'no rational view' test is not, in my opinion, consistent with a statutory test which expressly requires a balancing process and tilts that process in the same direction as that which the joint judgment in Pfennig suggested, but by the use of different terminology, that is 'substantially'. 100

Hidden and Buddin $\mathrm{JJ}$ sought to interpret the provisions as rendering the test for admissibility more strict. Their Honours stated:

Underlying the various formulations of the test for admission of similar fact or propensity evidence in the common law authorities is the recognition that evidence of that kind is likely to be highly prejudicial, and of the need to ensure that it is admitted only when the interests of justice require it. Its admission at common law is exceptional for reasons of policy, not logic. These considerations should guide the balancing exercise required by the statutory provision, so that the test for admissibility under that provision remains one of very considerable stringency. ${ }^{101}$

Spigelman CJ, however, specifically rejected this gloss on the provisions, stating that 'the statutory formulation should operate in accordance with its terms'. ${ }^{102}$

${ }^{97} R v A H$ (1997) 42 NSWLR 702; $R v$ Lock (1997) 91 A Crim R 356; $R v$ Fordham (1997) 98 A Crim R 359; $R v$ Ogd (2000) 50 NSWLR 433. Contrast with $W v$ The Queen (2001) 189 ALR 633.

98 The decision in Pfennig was handed down on 17 February 1995. The Commonwealth Act was passed on 2 February 1995 and came into force on 18 April 1995. The New South Wales Act was passed on 19 June 1995 and came into force on 1 September 1995. The bills had gone before the parliaments in 1993 and were based upon draft legislation contained in a report of the Australian Law Reform Commission, Evidence, Report No 38 (1987).

${ }_{99}$ (2003) 58 NSWLR 700.

100 Ibid 717 .

101 Ibid.

102 Ibid 719. The High Court initially granted leave to appeal, and then rescinded leave: Transcript of Proceedings, Ellis $v$ The Queen [2004] HCATrans 488 (1 December 2004). See also $R v$ Mason (2003) 140 A Crim R 274; $R v$ Gibbs (2004) 
In 2005, the Australian Law Reform Commission and the Law Reform Commissions of New South Wales and Victoria completed a review of the uniform Evidence Acts. In their Report, the view of Spigelman CJ in $R v$ Ellis is accepted as correct in principle. ${ }^{103}$ The Commissions' express preference for the current provisions of the uniform Evidence Acts rather than the Victorian re-statement of the common law is discussed below. ${ }^{104}$

\section{Statutory Modification of the Common Law}

In Queensland, legislation was introduced in 1997 which had the effect of abolishing the Hoch 'no possibility of concoction' test while not affecting the Pfennig 'no rational explanation consistent with innocence' test. ${ }^{105}$

In Victoria, in the same year more far reaching legislation was introduced with the intention of overturning the "no rational view of the evidence consistent with innocence' test, and re-instating the common law as it was prior to the decisions in both Hoch and Pfennig. In seeking to re-state the preHoch/Pfennig law, the draftsperson looked to the formulation adopted by the House of Lords in $D P P v P{ }^{106}$ considered below. In DPP $v P$, Lord Mackay, with whom Lords Keith, Emslie, Templeman and Ackner agreed, stated that propensity evidence will be admissible where 'its probative force in support of the allegation that an accused person committed a crime is sufficiently great to make it just to admit the evidence, notwithstanding that it is prejudicial to the accused in tending to show he was guilty of another crime'. ${ }^{107}$

146 A Crim R 503; $R v$ Milton [2004] NSWCCA 195; $R v$ Folbigg [2005] NSWCCA 23. Note however, that in Tasmania $v S$ [2004] TASSC 84, Underwood J stated at [11] that 'if there is a reasonable possibility of concoction, then the prejudicial effect will ordinarily outweigh the probative value of the tendency or coincidence evidence'. 103 Australian Law Reform Commission, New South Wales Law Reform Commission and Victorian Law Reform Commission, Uniform Evidence Law, ALRC Report No 102, NSWLRC Report 112, VLRC Final Report (2005), 382-4.

${ }_{104}$ Ibid 384-6.

${ }^{105}$ Section 132A of the Evidence Act 1977 (Qld) provides: In a criminal proceeding, similar fact evidence, the probative value of which outweighs its potentially prejudicial effect, must not be ruled inadmissible on the ground that it may be the result of collusion or suggestion, and the weight of that evidence is a question for the jury, if any. See Phillips v The Queen [2006] HCA 4.

${ }_{106}$ [1991] 2 AC 447.

107 Ibid 460. 
Section 398A(2) of the Crimes Act 1958 (Vic) follows the language of DPP $v$ $P$, stating that propensity evidence relevant to facts in issue in a proceeding is admissible if the court considers that in all the circumstances it is just to admit it despite any prejudicial effect it may have on the person charged with the offence'. ${ }^{108}$ Sub-section (3) specifically provides that the "possibility of a reasonable explanation consistent with the innocence of the person charged with an offence is not relevant to the admissibility of evidence referred to in sub-section (2).' In $R \quad v$ Best, ${ }^{109}$ Callaway JA analysed the provision, concluding that the 'flexibility of the test in sub-section (2) means that, properly applied, it will not greatly alter the conduct of criminal trials' ${ }^{110}$ His Honour concluded:

Propensity evidence is admissible only if its probative value is such that it is just to admit the evidence despite any prejudicial effect it may have on the accused. All the circumstances bearing on probative value and prejudicial effect are relevant, but not factors impugning the reliability of the evidence. ${ }^{111}$

Legislation achieving a similar result was enacted in Western Australia in 2004. ${ }^{112}$ In Western Australia the formulation used, however, is the

108 Section 398A provides:

(1) This section applies to proceedings for an indictable or summary offence.

(2) Propensity evidence relevant to facts in issue in a proceeding for an offence is admissible if the court considers that in all the circumstances it is just to admit it despite any prejudicial effect it may have on the person charged with the offence.

(3) The possibility of a reasonable explanation consistent with the innocence of the person charged with an offence is not relevant to the admissibility of evidence referred to in sub-section (2).

(4) Nothing in this section prevents a court taking into account the possibility of a reasonable explanation consistent with the innocence of the person charged with an offence when considering the weight of the evidence or the credibility of a witness.

(5) This section has effect despite any rule of law to the contrary.

For discussion of this provision, see $R v$ Best [1998] 4 VR 603; $R v$ Tektonopoulos [1999] 2 VR 412; $R$ v Mateiasevici [1999] 3 VR 185; $R$ v Cogley [1999] 3 VR 366; $R$ $v$ Dupas (No 2) [2005] VSCA 212.

109 [1998] 4 VR 603.

110 Ibid 612.

111 Ibid 616.

112 Section 31A of the Evidence Act 1906 (WA), as amended by the Criminal Law Amendment (Sexual Assault and Other Matters) Act 2004 (WA), provides:

(1) In this section - 
particularly inelegant one of whether 'the probative value of the evidence compared to the degree of risk of an unfair trial, is such that fair-minded people would think that the public interest in adducing all relevant evidence of guilt must have priority over the risk of an unfair trial.'

\section{ADMISSIBILITY}

\section{A General}

In seeking to achieve a proper balance between considerations favoring admission and those favouring rejection of propensity evidence, the fact that the accused possesses a propensity towards criminal behavior of any class cannot be sufficient to justify admissibility. In Phillips $v$ The Queen, in a joint judgment Gleeson CJ, Gummow, Kirby, Hayne and Heydon JJ stated:

Criminal trials in this country are ordinarily focused with high particularity upon specified offences. They are not, as such, a trial of the accused's character or propensity towards criminal conduct. That is why, in order to permit the admission of evidence relevant to several different offences, the common law requires a high threshold to be

'propensity evidence' means -

(a) similar fact evidence or other evidence of the conduct of the accused person; or

(b) evidence of the character or reputation of the accused person or of a tendency that the accused person has or had;

'relationship evidence' means evidence of the attitude or conduct of the accused person towards another person, or a class of persons, over a period of time.

(2) Propensity evidence or relationship evidence is admissible in proceedings for an offence if the court considers -

(a) that the evidence would, either by itself or having regard to other evidence adduced or to be adduced, have significant probative value; and

(b) that the probative value of the evidence compared to the degree of risk of an unfair trial, is such that fair-minded people would think that the public interest in adducing all relevant evidence of guilt must have priority over the risk of an unfair trial.

(3) In considering the probative value of evidence for the purposes of subsection (2) it is not open to the court to have regard to the possibility that the evidence may be the result of collusion, concoction or suggestion. 
passed. The evidence must possess particular probative qualities; a strong degree of probative force; a really material bearing on the issues to be decided. ${ }^{113}$

Nonetheless, in determining when the threshold justifying admissibility is reached, considerations relating to the nature of the case and patterns of offending behavior may be relevant considerations. Sexual offences against children are a class of case in which propensity evidence is very often most crucial to the prosecution. Most child sex offending takes place in the offender's home or in other private locations, with the result that typically there will be no independent witnesses available to support the prosecution's case. Victims of paedophiles and incest offenders are typically fearful and reluctant to report what has occurred, and are often subject to the influence of the offender to remain silent. In consequence, many child sexual abuse cases are conducted months or years after the event. In such cases there will be no medical evidence corroborating the victim's account of abuse. The fact of delay may lead to jury directions favourable to the accused. ${ }^{114}$ If the only evidence directly incriminating the accused is the evidence of the victim and the accused denies the victim's testimony, it is difficult for the prosecution to establish its case beyond reasonable doubt. If, however there is admissible evidence of similar acts committed by the accused, the victim's account becomes much more credible and the chances of conviction are significantly increased.

On the other hand, the dangers inherent in propensity evidence generally are greatly enhanced in sexual offence cases. ${ }^{115}$ The relevance of propensity evidence in paedophaelia cases is almost always via propensity, and the subject matter is one where the passions of a jury are likely to be at its highest. Accordingly, in such cases defence arguments that propensity evidence be excluded have particular force.

${ }^{113}$ [2006] HCA 4 [79].

${ }^{114}$ Longman v The Queen (1989) 168 CLR 79; Doggett v The Queen (2001) 208 CLR 343. For analysis of the requisite warning, see CR Williams, "Warnings Occasioned by Delay in Paedophile Prosecutions' (2003) 27 Criminal Law Journal 70.

115 That prejudice is at its strongest in sexual cases, and particularly those involving children is supported by research carried out by Dr Lloyd Bostock on mock juries; Law Commission, Consultation Paper, Evidence in Criminal Proceedings: Previous Misconduct of A Defendant (1996), Appendix D, referred to in Law Commission, Final Report, Evidence of Bad Character in Criminal Proceedings (Cm 5257, October 2001) at paras 6.37-6.42. Further research addressing the effect of such evidence on magistrates revealed a similar pattern, Law Commission, Final Report, Appendix A. 
In DPP v Boardman, the House of Lords had used the expression 'striking similarity' to describe the similarity between the accounts given by the two boys, ${ }^{116}$ and it was this similarity which gave the evidence its probative force and led to the evidence being admitted. This expression would seem to have been intended as no more than a method of expressing the probative force of the evidence in the particular case. Its alliterative attractiveness no doubt helped it to become regarded as itself the test for admissibility of propensity evidence. ${ }^{117}$ In cases of paedophilia however, the evidence typically does not derive its primary significance from anything strikingly unusual in the manner of committing offences. Its significance rests rather in features of a calculated, repetitive, obsessive and predatory nature which are common characteristics of the paedophile.

The matter was considered by the House of Lords in $D P P v P .^{118}$ The accused was charged with rape and incest against each of his two daughters, B and S. The trial judge rejected an application for severance on the basis that the evidence of each girl was admissible in respect of the counts relating to the other girl. The accused was convicted on one count of rape and all counts of incest in respect of each girl. There was no particular similarity in the course of conduct followed by the accused in respect of each girl. On appeal, the Court of Appeal felt constrained to allow the appeal, while stating there was force in the suggestion that the sexual domination exercised by the accused over his daughters might in itself provide a sufficient hallmark to render the evidence of one girl admissible in the case of the other. ${ }^{119}$

The prosecution appealed successfully to the House of Lords. Delivering the judgment of their Lordships, Lord Mackay LC stated that it is not appropriate to single out 'striking similarity' as an essential element in every case of propensity evidence. His Lordship stated:

The essential feature of evidence which is to be admitted is that its probative force in support of the allegation that an accused person committed a crime is sufficiently great to make it just to admit the evidence, notwithstanding that it is prejudicial to the accused in tending

\footnotetext{
${ }^{116}$ DPP v Boardman [1975] AC 421, 441 (Lord Morris); 444 (Lord Wilberforce); 455 (Lord Hailsham); 460 (Lord Cross); 462 (Lord Salmon).

${ }^{117}$ See $R$ v Inder (1977) 67 Cr App R 143; $R$ v Clarke (1977) 67 Cr App R 398; $R v$ Scarrott [1978] QB 1016; $R$ v Lunt (1987) 85 Cr App R 241; $R v$ Brooks (1990) $92 \mathrm{Cr}$ App R 36.

${ }_{118}[1991] 2$ AC 447.

119 Ibid 453.
} 
to show that he was guilty of another crime. Such probative force may be derived from striking similarities in the evidence about the manner in which the crime was committed and the authorities provide illustrations of that of which $R v$ Straffen and $R v$ Smith provide notable examples. But restricting the circumstances in which there is sufficient probative force to overcome prejudice of evidence relating to another crime to cases in which there is some striking similarity between them is to restrict the operation of the principle in a way which gives too much effect to a particular manner of stating it, and is not justified in principle. $^{120}$

His Lordship held that the sexual domination of a father over his daughters, which always takes some particular form, might itself be regarded as sufficiently uncommon or distinctive to warrant admissibility as propensity evidence. His Lordship stated:

In the present case the evidence of both girls describes a prolonged course of conduct in relation to each of them. In relation to each of them force was used. There was a general domination of the girls with threats against them unless they observed silence and a domination of the wife that inhibited her intervention. The defendant seemed to have an obsession for keeping the girls to himself, for himself. The younger took on the role of the elder daughter when the elder daughter left home. There was also evidence that the defendant was involved in regard to payment for the abortions in respect of both girls. In my view these circumstances taken together gave strong probative force to the evidence of each of the girls in relation to the incidents involving the other, and was certainly sufficient to make it just to admit that evidence notwithstanding its prejudicial effect. ${ }^{121}$

\section{B Types of Case}

Typically, paedophilia offenders are known to their victims, and no issue of identity arises. Where identity is an issue, paedophilia cases involve issues no different from other sexual offence cases where identity is disputed, and a strict test of admissibility requiring particular unusual or similar features is

120 Ibid 460.

121 Ibid 461. 
applied. ${ }^{122}$ Most paedophilia cases, however, involve offenders falling into one of two classes. First, cases of incestuous paedophilia. These are cases where the offender preys upon a number of his children or members of an extended family. Here there is no dispute as to identity, and the issue is usually whether the allegations made against the accused are founded in fact or malicious concoctions. Second, cases of predatory offenders. These are cases where an adult offender consistently, often over many years, preys upon children. The offender will commonly pursue a career (school teacher, priest or social worker) or social activities that place him in frequent contact with, and invest him with a degree of power within the group or groups from which his victims are chosen.

Whichever class of case is involved, the fact that paedophilia is involved is not of itself sufficient to render propensity evidence admissible. In England in the first half of the $20^{\text {th }}$ century, an exception to the first branch of Lord Herschell's formulation developed to the effect that in cases of abnormal sexual activity propensity evidence is admissible - the so-called 'hallmark' doctrine. ${ }^{123}$ In DPP $v$ Boardman the House of Lords firmly rejected the doctrine. ${ }^{124}$ The hallmark doctrine developed in relation to homosexuality, and was grounded in prejudice rather than logic. ${ }^{125}$ Homosexuality is not and never was sufficiently uncommon or particularised to justify such a doctrine. The rejection of such a doctrine, however, is also correct in relation to paedophilia. While the percentage of members of the community prepared to engage in paedophilia is quite limited, membership of such a class cannot of itself be regarded as sufficiently probative without more to justify the admissibility of propensity evidence. ${ }^{126}$ The development and rejection of the hallmark doctrine remains a potent reminder of the need to proceed with care in considering the admissibility of propensity evidence in relation to any class of sexual offence.

122 Sutton $v$ The Queen (1984) 152 CLR 528; $R$ v Tektonopoulos [1999] 2 VR 412. Note Rosemary Pattenden, 'Similar Fact Evidence and Proof of Identity' (1996) 112 Law Quarterly Review 262.

${ }^{123}$ Thompson $v$ The King [1918] AC 221; $R$ v Sims [1946] 1KB 531; $R$ v Hall [1952] $1 \mathrm{~KB} 302 ; R v$ King [1967] 2 QB 338.

124 DPP $v$ Boardman [1975] AC 421; see in particular the judgments of Lord Hailsham at 455-6 and Lord Wilberforce at 443.

125 See in particular the judgment of Lord Sumner in Thompson $v$ The King [1918] AC 221, 235.

${ }^{126}$ The same is true of other forms of abhorrent sexual activity such as sadism. See generally $R v$ Jeffries (1946) 47 SR (NSW) 384; $R v$ Witham [1962] Qd R 49; $R v$ Flack [1969] 2 All ER 784; $R v$ Clarke (1977) 67 Cr App R 398, note 117; $R v$ Wright (1990) 90 Cr App R 325; $R v$ BA [1997] 2 Cr App R 88; $R v$ Glennon [1993] 1 VR 97. 


\section{Relationship Evidence}

Evidence of other offences committed against the same victim is normally admissible. ${ }^{127}$ Such evidence is termed relationship evidence, ${ }^{128}$ and may either be the subject of separate counts or may be allegations of uncharged offences. Here the evidence possesses significant probative value as showing a passion directed towards a particular victim, and is relevant also as bearing on the nature of the relationship between victim and accused. ${ }^{129}$ In $R v$ Nieterink, Doyle CJ explained the significance of relationship evidence in child sexual abuse cases as follows:

This evidence may disclose a course of events leading up to the first charged incident, which enables the jury to understand that the incident did not, as it were, 'come out of the blue'. The evidence will also sometimes explain how the victim might have come to submit to the acts the subject of the first charge ... The evidence of uncharged acts may also ... make it believable or understandable that the victim might not have complained about the incidents charged until much later in the piece, if at all ... The evidence was also relevant because it could establish a sexual attraction on the part of the accused to [the complainant]. ${ }^{130}$

For relationship evidence to be admissible, the other offences must be established by evidence that is not limited to the testimony of the victim. Testimony by the victim as to such offences if unsupported by other evidence does not possess sufficient probative weight to justify admissibility having regard to its significant potential for prejudice. ${ }^{131}$

${ }^{127} R$ v Ball [1911] AC 47; $R$ v Gellin (1913) 13 SR (NSW) 271; $R$ v Etherington (1982) 32 SASR 230; $R v$ Dolan (1992) 58 SASR 501; $B v$ The Queen (1992) 175 CLR 599; $R v$ Beserick (1993) 30 NSWLR 510; $R v$ AH (1997) 42 NSWLR 702; $R v$ Josifoski [1997] 2 VR 68; $R$ v Wackerow [1998] 1 Qd R 197; $R$ v Grech [1997] 2 VR 609; $R$ v Nieterink (1999) 76 SASR 56; KRM v The Queen (2001) 206 CLR 221. Contrast with Gaudron J in Gipp v The Queen (1998) 194 CLR 106; R v Young [1998] 1 VR 402.

128 See above $\mathrm{n} 66$.

129 This might not, however, be enough to satisfy the Pfennig test of admissibility. In KRM v The Queen (2001) 206 CLR 221, McHugh J sought to resolve this difficulty by suggesting the Pfennig test is not applicable to 'relationship' evidence. See also $R$ v Nieterink (1999) 76 SASR 56; Conway v The Queen (2000) 172 ALR 185.

130 (1999) 76 SASR 56, 65.

131 Gipp v The Queen (1998) 194 CLR 106. 


\section{The Significance of Pattern of Offending Behaviour}

In cases involving different victims the fact that the accused possesses a propensity for paedophilia will not of itself be sufficient to justify admissibility. To insist, however, that there must be some 'striking similarity' or peculiar modus operandi raises the bar for admissibility unduly high, and posits a test that is not suitable for resolution of the issues involved. The significance of the evidence is that it demonstrates a particularized pattern of offending behaviour on the part of the accused. Further, the testimony of each victim supports that of the others. Were a single allegation made by a daughter against her father or by a child against a priest or youth worker, a jury might be disinclined to accept the possibility of a respected member of the community conducting himself in such a manner. Where there are a number of such allegations the evidence of each witness provides powerful support for that of the others. These considerations may not justify admissibility in particular cases, but they are considerations to be taken into account in the balancing process. Such evidence may of course raise issues of possible concoction on the part of the alleged victims, and careful directions on this possibility must be given to the jury. Given the privacy and the absence of other evidence which is characteristic of this type of offence however, not to recognise the force of this form of reasoning as supporting the case for admissibility may be tantamount to rendering the accused immune from successful prosecution.

The Ontario Court of Appeal recognised these considerations in $R v B(L) .{ }^{132}$ The decision involved two appeals heard together. In the first case, the accused was convicted of sexual assault against his stepdaughter. At trial evidence was received of sexual incidents involving his two natural daughters and the younger sister of his first wife. In the second case, the accused was a teacher convicted of offences against former students. At trial evidence was received of incidents involving other former students of the accused. In each case, the incidents comprising the propensity evidence took various and in no way unusual or distinctive forms. The Court dismissed the appeals of both accused. Delivering the judgment of the Court, Charron JA stated:

Focusing on the specifics of the allegation assists in the assessment of the extent to which the evidence of prior discreditable conduct supports the inference that the complainant's allegation is true. It stands to reason that, in this type of case, the more similar the complaints are, the higher the probative value ... It is also important to consider which

132 (1997) 116 CC (3d) 481. 
similarities are truly compelling. In cases of sexual assault, the similarities or dissimilarities between the sexual acts that are alleged are, of course, relevant, but often not as compelling as the circumstances surrounding the incidents. This stands to reason, particularly where there is nothing unusual about the sexual acts in question. In most circumstances, the fact that one complainant was kissed as compared to the other being fondled may not have a whole lot of significance. The allegations all pertain to acts of a sexual nature. In the same way, and again depending on the circumstances, the fact that assault occurred in the basement as opposed to the other in the bedroom may not be of consequence on the question of probative value. The different location may simply be attributable to a different opportunity for privacy. ${ }^{133}$

The significance of this line of approach is illustrated by the two cases of $R v$ Glennon. ${ }^{134}$ The accused had been a Catholic priest and youth worker who was alleged, over the period between 1970 and 1980, to have taken advantage of his position of authority systematically to abuse sexually adolescent males and females in his charge. In the first case the trial took place in 1991, prior to the enactment of s398A of the Crimes Act 1958 (Vic). The trial judge directed the jury that in respect of a number of counts evidence relating to other counts could be used as propensity evidence. The Court of Criminal Appeal upheld the decision of the trial judge, applying the 'striking similarity' test. The decision of the court was, it is submitted, correct. The evidence established a highly probative pattern of offending behaviour on the part of the accused, and that of the others supported the evidence of each boy. It seems forced, however, to achieve the result of admissibility through application of the 'striking similarity' test. The offences did not exhibit significant features distinguishing them from the normal run of case involving an adult in a position of authority and power systematically using that position to exploit sexually young people in his charge.

The second case was on appeal from convictions at two trials, the first of which involved 29 counts of various sexual assaults against six separate complainants. The judge ruled that evidence in respect of each of the counts was mutually admissible, and refused an application for severance of the counts involving one particular complainant from the counts involving other complainants. The accused was convicted on 24 counts, and unsuccessfully appealed to the Court of Appeal. The cross-admissibility of the evidence

133 Ibid 499-500.

$134 R v$ Glennon [1993] 1 VR 97; Rv Glennon (No 2) (2001) 7 VR 631. 
relating to the various counts was now governed by s 398A of the Crimes Act 1958 (Vic). The Court of Appeal held that severance was properly not ordered if all the evidence was mutually admissible, and that the ruling of the trial judge on mutual admissibility was correct. Callaway JA stated:

The applicant was known to each of [the complainants] as a priest and in other leadership roles ... In all those roles the applicant was in a position to exercise, and did exercise, strict discipline over children of a vulnerable age. He was in a position of trust derived from his personal standing, as well as his standing as a priest, with the children's families. The evidence of the complainants, taken together, pointed strongly to a pattern of conduct on the part of the applicant, involving the systematic exploitation of vulnerable children within his domain in a similar manner. The probative value of the evidence lay in the improbability of six complainants giving such connected accounts unless those accounts were true. ${ }^{135}$

A similar case is $R v$ Liddy. ${ }^{136}$ The accused was a magistrate and coach of junior surf lifesavers. It was alleged he had over a period of years used his position of authority sexually to molest young boys. The accused was charged on 15 counts involving 5 boys between the ages of 8 and 13 years and convicted of 9 counts involving 4 of the boys. No issue of possible joint concoction arose, the complaints being made years later when the victims were adults and no longer associated with one another. Had the case arose while the boys still had contact with one another, a strict application of the Hoch/Pfennig test would almost certainly have led to inadmissibility. The trial judge refused to order severance and held the evidence on the counts crossadmissible. The Supreme Court of South Australia upheld the decision of the judge. Mullighan J summarised the significance of the evidence as follows:

It is capable of negativing innocent association between the appellant and each of the boys. It is capable of amounting to corroboration or confirmation of the evidence of each complainant about each charged act relating to him. The evidence is capable of proving that the incidents occurred and all complaints relating similar events is not a matter of pure coincidence. It is capable of proving the objective improbability of each of the complainants giving accounts of sexual conduct by the appellant unless those accounts are true and there is no

135 Ibid 673. Application for leave to appeal to the High Court was refused on 15 February 2002.

136 (2002) 81 SASR 22. 
reasonable view of the evidence other than as supporting an inference that the appellant is guilty of the charge under consideration. The evidence could negative innocent association. Furthermore, it is capable of establishing a sexual attraction on the part of the appellant to the complainants and to put their evidence into true context. Also, the evidence is capable of establishing that he used the group of boys and the activities which he provided for them as the opportunity for his offending. ${ }^{137}$

In $R v$ Glennon (No 1) and $R v$ Liddy, the court was able to hold the propensity evidence admissible. The strictness of the Hoch/Pfennig test, however, raises doubts as to whether the evidence was in fact properly received in the application of that test. In this respect the test posited in DPP $v P$ and s 398A of the Crimes Act 1958 (Vic) is more satisfactory. It does not impose restrictions on the manner in which the propensity evidence derives its probative force, and consideration of whether it is just to admit the evidence invests the judge with considerable flexibility in determining whether in all the circumstances of the case reception of the evidence is justified. The position under the uniform Evidence Acts is likewise preferable to the Hoch/Pfennig approach. While the uniform Evidence Acts perhaps raise the bar to admissibility through the requirement that the probative value of the evidence 'substantially' outweighs its prejudicial effect, the test retains the flexibility of the common law approach in determining whether in all the circumstances of the case the evidence justifies admissibility notwithstanding its potential for prejudice.

\section{CONCLUSION}

In their habitual offending behaviour, paedophiles seek to establish opportunity and overcome the child's resistance to the sexual acts, typically through a grooming process in a manner calculated to minimise the risk of detection. It is this very process or pattern of conduct which creates significant obstacles to the prosecution of paedophilia offences - the sexual abuse usually takes place in private and child victims frequently do not report abuse when it occurs. Evidence of similar misconduct of the accused may be highly probative in establishing this pattern of paedophilia behaviour, and its reception particularly valuable where the only other evidence available is the complainant's testimony. Child sexual abuse is not of itself sufficiently specialised to render propensity evidence admissible. It is, however,

137 Ibid 45. 
legitimate for the courts to have regard to the totality of the overall scheme of offending in determining the probative value of the evidence.

Evidence of acts against the same complainant (relationship evidence) whether charged or uncharged is highly probative in establishing the sexual nature of the relationship between the accused and complainant, and is generally regarded as sufficiently probative to justify admissibility on this basis. Evidence of sexual misconduct against other child complainants is relevant to establishing the objective improbability of the accused not having committed the crime. In cases where identity is in issue, as the only thing connecting the accused to the offences is the method of attack, unless that method is highly similar, the evidence fails to establish its purpose and should not be admitted. The position is different where the complainant knows the offender. Here the circumstances surrounding the sexual abuse may be highly probative in establishing the systematic exploitation of vulnerable children by a person in a position of trust and authority.

Application of the Hoch/Pfennig test is unduly favourable to the accused and ought to be reconsidered by the High Court. Such an approach serves to deny the high probative value of the evidence, in circumstances where the very nature of offending causes the judge to find that there is another rational view of the evidence consistent with the innocence of the accused. Both the provisions of the uniform Evidence Acts and the pre-Hoch/Pfennig common law, embodied in s 398A of the Crimes Act 1958 (Vic), provide more satisfactory approaches to determining admissibility. 